\title{
New frontiers in international retirement migration
}

\author{
Russell King ${ }^{1 \star}$ (D), Eralba Cela ${ }^{2}$ and Tineke Fokkema ${ }^{3,4}$ \\ ${ }^{1}$ Department of Geography, School of Global Studies, University of Sussex, Brighton, UK, ${ }^{2}$ Department of \\ Social and Political Sciences, University of Milan, Milan, Italy, ${ }^{3}$ Netherlands Interdisciplinary Demographic \\ Institute (NIDI-KNAW), University of Groningen, Groningen, The Netherlands and ${ }^{4}$ Department of \\ Public Administration and Sociology, Erasmus School of Social and Behavioural Sciences (ESSB), Erasmus \\ University Rotterdam, Rotterdam, The Netherlands \\ ${ }^{*}$ Corresponding author. Email: r.king@sussex.ac.uk
}

(Accepted 27 January 2021)

\begin{abstract}
Introducing the special issue, this paper provides a state-of-the-art on established and new trends in the study of international retirement migration (IRM) and summarises the five papers that follow. Early studies on IRM were mainly within Europe and drew on the conceptual framework of lifestyle migration, with some reference to the transnational and mobilities paradigms. New frontiers in IRM are presented under three heads. Firstly, new geographical frontiers extend IRM to new destinations within and proximate to Europe, and to new locations in the global South such as Thailand and Ecuador. Secondly, new typological frontiers involve a broadening of the class and wealth backgrounds of the retirees, including the 'return of retirement' of labour migrants to their countries of origin, and attentiveness to IRM's gendered aspects. Thirdly, new conceptual and theoretical frontiers of IRM involve a more in-depth investigation of its transnational aspects, exploration of the various regimes of mobility and, most importantly, a political economy perspective which stresses global inequalities and histories of colonialism in shaping access to privileged lifestyles. In the final part of the paper, the original features of each paper in the special issue are highlighted, demonstrating how they are collectively integrated and contribute to the advancement of IRM research.
\end{abstract}

Keywords: international retirement migration; lifestyle migration; transnationalism; mobilities paradigm; political economy approach; geoarbitrage

\section{Introduction}

International retirement migration (IRM) lies at the intersection of two major socio-demographic trends reshaping global population: ageing and migration. Yet research on IRM as an empirically investigated phenomenon has been quite recent, starting in the late 1990s; even more recent have been attempts to frame IRM in a theoretical context. In this special issue, consisting of an introductory overview and 
five substantive papers, ${ }^{1}$ we aspire to extend the existing literature on IRM in new directions, justifying the epithet 'new frontiers'. The directions pursued are threefold: extending the geographical frontiers of IRM; exploring new typologies and motivations; and advancing theoretical understanding of an increasingly diversified phenomenon. At the same time, we aim to nuance and problematise the very definition of 'international retirement migration' by unpacking its constituent parts.

\section{Early studies on IRM}

Like other forms of migration, the international dimension of IRM was historically linked to an earlier process of internal retirement migration. In their review of the history of British retirement migration, King et al. (2000: 19-22) note the development of retirement migrations from London and the main industrial combinations to coastal residential resorts, especially along the South Coast, in the 1920s and 1930s. Similar phenomena were observed in France, Belgium and other European countries. Likewise, in the United States of America (USA), retirement migration developed vigorously in the inter-war period, with large concentrations of white-collar retirees in southern California and Florida. In all the above-mentioned areas, these retirement flows and settlements continued into the post-war era and are still ongoing.

The international dimension of retirement migration is more recent, a consequence of the post-war tourism boom which, from modest beginnings, gathered pace from the 1960s and 1970s. The mass-marketing of holiday packages to Mediterranean coastal resorts brought millions of Northern Europeans to the southern shores of the continent; and thus were sown the seeds of retirement migration to these hot, sunny locations (Williams et al., 2000). It is not easy to trace the first piece of academic scholarship on this type of IRM, but an early study by Myklebost (1989) on 'the migration of elderly Norwegians' described the development of Norwegian retirement communities in southern Spain and the Canary Islands, with both long-term residents and 'snowbirds' who flew south every year to escape the harsh Nordic winter.

Work on IRM developed further from the late 1990s and accelerated swiftly after the turn of the millennium with, now, a plethora of studies too numerous to list here. Better, instead, to give a series of significant staging posts. This starts with Hoggart and Buller's (1995) paper in this journal on British retirees in rural France, continues with the statistical overview of IRM from Northern to Southern Europe by Williams et al. (1997), and culminates, in this initial phase of scholarly literature, with the special issue of the International Journal of Population Geography on 'International Retirement Migration in Europe' edited by King et al. (1998).

For a time, Mediterranean Europe was almost the exclusive focus for IRM research, for three main reasons. First, and most obviously, this was where the main concentrations of such migrants were located, especially along the coasts of southern and eastern Spain, plus the Balearic and Canary Islands. Second, geographical access was easy for European researchers. Third, fieldwork was straightforward, since most retirees had time on their hands and were willing to engage in lengthy interviews. Book-length studies proliferated, especially in the 2000s (see King et al., 2000; O’Reilly, 2000; Huber, 2003; Rodríguez et al., 2005; Oliver, 2008). Two further special issues of key journals were published on older migrants 
in Europe - Ageing \& Society (Friedrich et al., 2004) and the Journal of Ethnic and Migration Studies (Warnes et al., 2006). Both contained papers on IRM, including a comprehensive review article (Casado-Díaz et al., 2004).

Much of the work published in this expansive phase of research in the late 1990s and 2000s used, either explicitly or implicitly, a 'lifestyle' approach to explain the reasoning behind the moves abroad to places where the physical setting (climate, coastal location, beautiful landscape) and the socio-cultural environment (food, cultural heritage, way of life) were seen as major attractions. This element was illustrated, for example, in the subtitle of Benson's (2011) landmark study of the British in rural south-west France: 'the ongoing quest for a better way of life'. The lifestyle lens quickly became the dominant approach to theorise IRM, evidenced in several edited books and papers by Benson, O'Reilly and others (see inter alia Benson and O'Reilly, 2009a, 2009b; Benson and Osbaldiston, 2014, 2016; Janoschka and Haas, 2014).

In their canonical definition, Benson and O'Reilly (2009b: 609-610) write that 'lifestyle migrants are relatively affluent individuals ... moving either part-time or full-time to places that, for various reasons, signify, for the migrant, a better quality of life'. They go on to say that 'lifestyle migration is thus a search, a project, rather than an act, and it encompasses diverse destinations, desires and dreams'. In fact, as the second part of this quote illustrates, there is an uneasy equation between IRM and lifestyle migration. The ethnographic studies by Benson (2011) in rural France and by O'Reilly (2000) on the Costa del Sol in Spain are not limited to retirees but also include younger working migrants attracted by the lifestyle of the place in which they have settled. Furthermore, the lifestyle element of migration decisionmaking also came to be applied to other, very different, forms of migration, e.g. the return migration of Pakistan migrants from England to Pakistan (Bolognani, 2014) or the migration of young European graduates to London (King et al., 2016).

Beyond the dominant framing of IRM as a lifestyle migration, two other theoretical links were also present, albeit not so prominently, in the interpretive writing about IRM in this period. The first of these was a transnational optic, indicated by the subtitle to O'Reilly's (2000) book on the British on the Costa del Sol, ${ }^{2}$ and more explicitly in a paper by Gustafson (2001) which drew out the transnationalism inherent in much IRM. Gustafson's research on Swedish retirees in the south of Spain documents a to-and-fro community with links - 'translocal place attachments' - to both their Swedish home and their Spanish base. His study also opens up the second theoretical theme: the extent to which IRM can be interpreted via the 'mobilities' paradigm (Urry, 2007). Both Gustafson (2001) and Åkerland and Sandberg (2015), who researched Swedish retirees in Malta, observe a wide spectrum of mobility regimes, from permanent resident, through seasonal snowbirding to more spontaneous, irregular and shorter-term visits. These studies, and others by O'Reilly (2003) and Williams et al. (2000), beg the question of whether IRM should better stand for international retirement mobility.

\section{New frontiers for IRM}

Beyond the 'lifestyle' approach, the structural parameters which have fostered the growth of 'conventional' IRM (such as that from Northern to Southern Europe) are well-known from the literature (King, 2012). They include demographic ageing 
and increasing life expectancy, on the one hand, and sustained personal wealth accumulation, on the other. Their combined effects have created a pool of prosperous baby-boomers and, more recently, younger cohorts of soon-to-be older people who will reach retirement age in the coming years. The spread of tertiary education amongst middle-to-older age groups when they were younger in the 1960s, 1970s and 1980s, plus a widespread habit of leisure travel and holidaying abroad, have improved both knowledge of and accessibility to warmer regions and attractive landscapes. Other structural factors are related to geopolitics, such as the establishment of the European free market for travel, residence, work and pensions transfer, and the North American Free Trade Agreement comprising Canada, the USA and Mexico, which favour mobility and relocation within these macro-regional domains.

Against this backdrop, IRM has been diversifying in recent years: new frontiers are opened up regarding its geographies, typologies and theorisation.

\section{Changing geographies of IRM}

The map of IRM is rapidly changing. Traditional destinations become passé and, in some perceptions, saturated with lifestyle and retirement migrants. An additional effect is that the prices of retirement properties, once relatively cheap, are pushed up by cumulative demand. Characterful rural properties in regions like Tuscany and Provence, or villas in prestigious coastal locations such as the French and Italian Rivieras, are no longer affordable to aspiring purchasers, who therefore look elsewhere. New geographical frontiers are opened up in regions, countries and continents not, or less, affected by the IRM phenomenon.

Some new frontiers are close to 'classic' IRM destinations. Cases in point are the Marche region, 'next door' to Tuscany in central Italy (King et al., 2019, 2021, this issue); or the Lot, adjacent to the better-known Dordogne in south-west France (Benson, 2011); or, in Portugal, alternative locations to the Algarve opened up in rural central Portugal (Sardinha, 2015) and, further afield, the Azores (Sampaio and King, 2019; Sampaio, 2021, this issue). In all these cases, the appeal of cheaper properties is reinforced by a quest for social distinction in coveting a more 'authentic' rural or insular space for the desired retirement lifestyle.

A second scale of geographical frontier involves enlarging the search space to different countries within the same broad continental or sub-continental region; for lovers of the Mediterranean climate, new destination countries such as Croatia and Bulgaria or, somewhat further afield, Morocco or Turkey. There is a growing awareness of this geographical spreading-out amongst real-estate brokers and in newspaper accounts, but little academic research thus far (but see Balkir and Kirkulak, 2009; Escher and Petermann, 2014; Gehring, 2019).

More extensive has been the research on IRM flows to the global South - notably to Latin America and South-East Asia. Mexico and Ecuador are the most favoured locations for North American international retirees, judging by the available published research, with some attention also to Panama. On Mexico, Lardiés Bosque et al. (2016) have researched the 'over-the-border' retirement communities in northern Mexico's Baja California, whilst others have documented retirees living in picturesque highland locations further south, such as San Miguel and Lake 
Chapala (Truly, 2002; Banks, 2004; Dixon et al., 2006; Sunil et al., 2007; Rojas et al., 2014). Research on Ecuador has focused on American older-age residents in the historic city of Cuenca (see Hayes, 2014, 2018, 2021, this issue; Miles, 2015). Hayes describes this North-to-South migration as 'geographic arbitrage' or 'geoarbitrage' - an economically driven strategy to pursue fulfilling retirement in low-cost locations.

Much the same principle applies to the lively research interest in retirement migration to South-East Asia where, according to Toyota and Biao (2012), there is now an 'emerging transnational retirement industry'. Thailand and, secondarily, Malaysia have been the main focus of attention. Here, several nationalities of retirees have been researched - British, German, Swedish and Japanese - and for a mix of relocation processes beyond the assumed 'normal' demographic unit of the retired couple. These modalities invoke the destination countries' reputation for affordable, high-quality care; the mechanism of marriage migration, nearly always between older European men and much younger local women; and the arbitrage of a low cost of living in a warm climate, enhancing the purchasing power (for housing, food, medical care and other services) of what might be otherwise considered as modest pensions (see inter alia Howard, 2008; Green, 2014; Ono, 2015; Wong and Musa, 2015; Horn et al., 2016; Toyota, 2016; Botterill, 2017; Scuzzarello, 2020).

\section{New typologies of IRM}

The second type of frontier which we seek to unpack, is the diversity in types of IRM. Some clues about this diversification have been given in the foregoing discussion. We observe that IRM is no longer an elite phenomenon which only relatively wealthy people can afford. Even in 'classic' destinations such as southern Spain, blue-collar retirees have been part of the expansion of the phenomenon, often buying or leasing flats and smaller houses on purpose-built developments. Those needing to spin out their pensions are appearing in new research; for instance, they are part of the migration of Swiss retirees to Morocco (see Bolzman et al., 2021, this issue). Many of the participants in Hayes' paper on Ecuador in this issue also describe how they would hardly be able to afford to 'live well' and pay for comprehensive health insurance if they lived in the USA. The switch, then, from a purely lifestyle and amenity-driven rationale to one which also embodies a hedge against precarity, is an important new dimension of IRM to be considered (Bender et al., 2018).

Also part of the unpacking of IRM is a closer examination between its two elements - 'international migration' and 'retirement'. This is largely an issue of timing. Whilst the former is easy to define - it is self-evidently a purposeful movement across an international frontier for a threshold measure of time, such as six months (as in seasonal IRM) or a year - the concept of retirement is not so clear-cut. In its narrowest meaning, IRM implies that the individual moves abroad at or soon after retirement. However, some people move abroad before they retire as a pre-planned relocation for a subsequent retirement; this is especially feasible for those who can work from home. For others, retirement is not an instantaneous event, but phased over a period of semi-retirement which, again, may coincide with a move abroad.

This kind of situation is part of a wider debate on the 'destandardisation' of lifestages and trajectories, where age boundaries, culturally and institutionally 
established, have become blurred and re-ordered. Retirement ages are also becoming more variable, spreading from early fifties in some professions (police, the military) to the possibility of continuing to one's seventies and later in academia and many freelance professions, such as the arts, business and consultancy. This is why the special issue papers cover a wide spectrum of age ranges, looking both at individuals who have moved abroad after retirement and at younger research participants who migrate in anticipation of retirement. One of the papers in the special issue (Lulle, 2021) actually 'reverses' the retirement-migration nexus by looking at people in the post-Soviet realm who reach retirement age and then migrate abroad to begin a new working life to stave off poverty and inactivity.

IRM is also a gendered phenomenon, reflecting the fact that all forms of migration and mobility are gendered, usually in a relational sense - the expectations and outcomes of migration of one gender are related to the behaviours and experiences of the other gender. For the conventional, amenity-oriented form of IRM, the heterosexual couple is quantitatively the most common unit; for instance, in a study of 1,066 IRM respondents in four destination countries, more than two-thirds were married couples in two-person households (King et al., 2000: 73-74). Obviously, this changes when one of the partners dies, so that single-person retiree households are also quite common - over a quarter in the same survey. The highly gendered phenomenon of older lone Japanese men who retire into seclusion in Thailand is described by Toyota (2016), as well as the privilege and power exerted by older Western men seeking younger Thai wives/partners/carers (Scuzzarello, 2020).

Different again is the developing strand of literature on later-life migration as an active-ageing strategy for older women-those who are single, widowed or divorced/separated (Gambold, 2013). Cases of the empowering effect of IRM for single women are also noted by Hayes (2021, this issue) and Sampaio (2018). Lulle and King (2016) and Lulle (2021, this issue) document the experiences of older Latvian women in the United Kingdom (UK) and Nordic countries who achieve self-realisation and economic independence through migrating for work in later life.

Taking the term 'international retirement migration' literally, another type of migration appears alongside the predominantly 'privileged' lifestyle migration to pleasant seaside, urban and rural environments. This is 'retirement return migration', whereby retired labour migrants decide to go back to their towns and villages of origin once their working life comes to an end. At this point in their lives, many labour migrants (and high-skilled migrants too) face a dilemma: either to return to their country of origin, which was generally their original plan; or to abandon any idea of return and continue their post-retirement lives in their chosen host country, close to their children and grandchildren (Bolzman et al., 2006; Ciobanu and Ramos, 2016). In Cerase's (1974) well-known typology of return migration, based on the historical experience of Italian migrants in the USA, the 'return of retirement' takes place after many decades in the USA, at a point when the 'pull of home' reasserts itself and retired migrants decide they want to live out their last years in their 'native air' and be buried in their 'ancestral soil'.

In the more numerous recent studies of this phenomenon in European host countries, the majority finding is 'stay' rather than 'return' - the location of children often being the critical variable (e.g. De Coulon and Wolff, 2010). Other studies, on 
male older migrants, reveal that return is more likely when the spouse and children are in the country of origin (de Haas and Fokkema, 2010; Cela and Bettin, 2018). However, European studies also reveal a preference for a 'back-and-forth' pattern of circulatory migration, in an attempt to enjoy the 'best of both worlds' (Bolzman et al., 2006; Ganga, 2006; Baykara-Krumme, 2013). The shorter distances involved in these migration systems - such as Switzerland to southern Italy, or Germany to Turkey - make this model of transnational living a feasible option, as long as good health and personal mobility are maintained (Fokkema et al., 2016). For those who have returned, usually leaving their children and grandchildren in the host country, regular family visits and holidays to enable the younger generations to see their parents and grandparents in Southern Europe enable some elements of 'transnational familyhood' to be sustained - see Rodríguez and Egea (2006) on Andalusia. In other cases, return migration to a rural, depopulated place of origin can be an isolating experience for retirees (Barrett and Mosca, 2013).

\section{Extending theoretical frontiers}

As noted earlier, initial theorisation of IRM mainly drew on the approach of lifestyle migration, with additional insights from the transnational and mobilities paradigms. The potential of these conceptual frameworks for shedding light on IRM is by no means exhausted; especially the latter.

Existing empirical research on IRM throws up divergent perspectives on retirees' transnational behaviour. On the one hand, the combination of long distances and the fact that some IRM decisions are based on the notions of escape and starting a new life abroad produce 'diminished transnationalism', noted by Botterill (2016) for the case of British retirees in Thailand. Likewise, Oliver (2016), researching ageing British retirees in southern Spain, observed how ties to the UK eroded over time, partly as a result of failing health and decreasing ability to travel back and forth. On the other hand, Gustafson's $(2001,2009)$ research on retired Swedes in southern Spain documents the various ways in which transnational life is actively sustained by 'transnational residential strategies' and 'circulating between two homes'. Taken in the round, however, the main focus of research on IRM is the retirees' lives in the destination setting; their transnational links to their home country and to other places where they have lived tend to get overlooked.

Much the same can be said about IRM as a specific example of cross-national mobility, viewed within the optic of the mobilities paradigm. The standard texts on the mobilities framework (Cresswell, 2006; Urry, 2007; Adey, 2010) make no mention of IRM, preferring to concentrate, when discussing corporeal mobility, on other forms of travel and migration, especially tourism. Yet IRM is considered by many of its researchers to be an interesting and difficult-to-classify form of international migration/mobility, as illustrated by the hybrid term 'residential tourism' (Janoschka and Haas, 2014). Scope certainly exists to examine in more detail, and more critically, the various spatio-temporal regimes of mobility associated with IRM: the range of temporalities spanning occasional, seasonal and permanent moves, and the ways in which other forms of mobility, such as visits and side-trips, are enfolded within the longer temporal movements that create IRM communities. 
In our reading, the main theoretical thrust towards a more complete, multi-level understanding of IRM derives from setting the phenomenon within a broader conceptual framework of 'global social transformation' (Castles, 2010). Such an approach pays particular attention to geographies of uneven development and postcoloniality, and the exercise of class, wealth and privilege across international boundaries. This is a line of argument which is well-developed by Benson (2013, 2015) and Hayes (2014, 2018; see also Hayes and Pérez-Gañán, 2017) in the context of Latin America as a 'new frontier' for IRM. These writings are emblematic of wider processes of retirement migration from affluent countries of the global North to less economically well-off countries of the global South. North-to-South IRM reveals the increasing global interconnectedness of ageing in different countries and raises crucial questions about global inequalities in regard to ageing, care, wealth and privilege.

According to Hayes and Pérez-Gañán, North-South IRM is illustrative of the changing political economy of late capitalism, whereby:

the symbolic and economic power of privileged global social positions are increasingly moved across borders to take advantage of emerging individual arbitrage opportunities in a globalized social field ... The relatively permissive mobility regimes governing individuals from the Global North enables an expansion of southward forms of transnationalism [such as long-distance IRM] to escape the inconveniences of social structural transformations resulting from severe economic crisis in developed societies. (Hayes and Pérez-Gañán, 2017: 117)

Moreover, North-South IRM brings into focus the coloniality of power at the heart of this form of transnational mobility, particularly in the context of an international migration regime which is highly restrictive towards movements in the other direction, for instance of Ecuadorians to the USA.

If there is one term that encapsulates the essence of this critical political economy approach, it is geoarbitrage. As Hayes describes it in his 2014 paper, geoarbitrage is one way of fulfilling neoliberal cultural ideals of perfectly efficient markets, relocating lower-income older individuals from the global North to geographic regions in the global South where they can maximise the marginal utility of their consumer desires, reproducing the coloniality of inherited structural inequalities.

The 'coloniality of inherited structural inequalities' does not necessarily imply a post-colonial reworking of exact former bilateral colonial relations, although this does hold in the cases of Malta for British retirees (Warnes and Patterson, 1998) or Panama for US retirees (Benson, 2013, 2015). Rather, the coloniality of power is exerted, via IRM, through the more systemic, symbolic privilege of membership of globally important nation-states such as the USA, UK or Germany. Seen in this light, the political economy of IRM is exercised through a combination of colonial history, uneven economic development and the neo-colonial process of mass tourism. Whether in Ecuador or Mexico, Thailand or Malaysia, or even Turkey or southern Spain, there is an urgent need to unpack the power dynamics that shape international retirement flows, recognising the nuances of how these unfold in different geographical contexts, including experiences of privilege structured 
around a range of intersecting dimensions - class, wealth, country of origin, colonial history, 'race' and so on (Benson, 2013: 328).

\section{The papers}

Following this introductory overview, five papers make up the special issue, sequenced in a manner that blends thematic and geographical continuity.

We start with two papers that are focused on the global South and exemplify a range of themes including geographic arbitrage, the 'outsourcing' of retirement support and active ageing as adventure. In the first of these, Matthew Hayes examines the retirement migration of mostly middle-class 'active agers' from the USA and Canada to Ecuador, and specifically to Cuenca, a UNESCO World Heritage city. In this example of the political economy of North-South uneven development, retirees on fixed pension incomes can take advantage of inherited global inequalities to improve both their material and cultural quality of life. In a powerful theoretical statement, Hayes argues that the 'crisis of neoliberalism', combined with growing inequality and increased financial insecurity of older people in North America, creates the space for geoarbitrage as the libertarian alternative to public policies of ageing in place. Hayes' 83 research participants are mostly 'third-age', typically in their sixties and early seventies, and physically and mentally active; they are enjoying a phase of adventure and cultural enrichment before they reach the 'fourth age' of decline leading to death. They are carpe diem migrants, seizing the moment in their lives to do something different and exciting whilst they can. As Hayes quotes in his title, 'You gotta get out of your comfort zone'. For Hayes' interviewees, this meant charity work, or dedicating themselves to physical wellbeing through dancing and exercise classes, or using Cuenca as a jumping-off point for side-trips to other countries in South America.

Despite the interviewees' collective portrayal of Cuenca as a kind of low-cost bohemian utopia for North American seniors, Hayes is alive to the danger of overcelebrating this third-age culture of adventurous and active ageing, pointing out how it is rooted in the intersection of two much wider realities. On the one hand, the narratives voice a neoliberal view of ageing, which assigns value to physical and social activities reminiscent of youth and individualism, but which masks the erosion of the publicly guaranteed economic security and solidarity of the welfare age, stripped away over recent decades. On the other hand, geoarbitrage enables these same individuals to engage in new types of international mobility, including IRM, which place them in low-income societies of the global South created by histories of colonialism and capitalist exploitation, where they use their pensions to buy themselves a lifestyle which is both materially and culturally richer than they would have experienced in their home countries.

In the second paper, Claudio Bolzman, Tineke Fokkema, Ibrahima Guissé and Danique van Dalen adopt a lifecourse perspective on the ageing of Swiss, Dutch and Flemish retirees and soon-to-be retirees in Morocco. Unique to this paper is an emphasis on the timing of the move to Morocco. Based on interviews with 42 participants aged at least 49 , the authors distinguish three groups according to their age when moving to Morocco: those who moved in early adulthood, before age 35; those who migrated at mid-adulthood, aged 35-55; and later-life retirement 
migrants. Also important for the analysis in this paper is the biographical concept of 'linked lives' - the ways that individuals are tied to family and social networks over time - and how these links impinge on, or are affected by, migration decisions.

The three age-arrival groups moved to Morocco for different sets of reasons, and experience different outcomes. For the first, youngest-arrival group, the main reasons for relocating to Morocco were twofold: either marriage to a Moroccan (in all cases, women marrying Moroccan men), or business and adventure motives (for European men). This group is long-settled in Morocco, where they are content to 'age in place'. The second group, who migrated in middle adulthood, are mostly tourist entrepreneurs; they are less 'integrated' into Moroccan society than the first group, and more uncertain about their present or future older-age lives. Most seem content to 'stay put' in retirement because of lower living costs and ongoing business commitments, but their social networks are mainly with other 'expats'. The third cohort are more akin to 'conventional' international retirement migrants, driven by a combination of lifestyle, climate and cost-of-living reasons. Many of the interviewees in this group had experienced disruptions in their lives, such as divorce, bereavement or health problems, and hence were also seeking a new start with a 'now or never' outlook. Although Switzerland, the Netherlands and Belgium are among the wealthiest countries in Europe, pensions inevitably represent a downshift to a much lower income in a setting of high living costs and, especially in Switzerland, expensive health care. Maintaining their previous living standards, when in full-time employment, becomes impossible on a pension. Hence, like the later-lifers in Cuenca, or the retirees in Thailand referenced earlier, precarious economic conditions in older age push people to 'escape' to somewhere which is not only warmer and more relaxing, but which also offers a much lower cost of living, including personalised health services.

The next paper, by Russell King, Eralba Cela, Tineke Fokkema and Gabriele Morettini, continues the theme of new geographical frontiers, this time taking readers to a 'near' frontier within an established IRM destination country, Italy. Theoretically, this paper is novel because of its concentration on the materialities of what is otherwise a fairly classic lifestyle migration, from Northern Europe to the Mediterranean. The materialities of older migrants' everyday practices, routines and consumption, including their residence choices and settlement patterns, have attracted little attention thus far in analyses of international relocation in later life. Three materialities are selected, based on narrative extracts from 69 interviews with British, Dutch and German participants: (a) the beautiful landscape of the Marche region, (b) the materialities of historic housing, property location and land, and (c) the consumption patterns of later-life migrants, based on principles of local production, environmental sustainability and landscape protection.

As the narrative extracts presented in the paper illustrate, most migrants hanker after what they perceive as a simpler, more 'genuine' way of life, in tune with the mixed-farming rural environment of this less-known Italian region. At the same time they deliberately seek out historic properties with far-reaching views. Many grow their own food, including vines and olives. They enjoy shopping in local markets, eating and drinking in local hostelries, and visiting local cultural attractions such as museums, churches and concerts. However, this set of materialities reflects a somewhat gilded imaginary of the local rural society and economy, which is 
subject to wider, global forces of competition, undermining the profitability of local farming and its ancillary activities. The research participants, who are mostly in their third age, enjoy their ability to pursue their particular version of active ageing, but those who are older or experiencing frailty must compromise and plan for a future where their care needs will be greater, eventually forcing a return to their country of origin

The final two papers make a more radical shift from IRM as a lifestyle-driven process for the relatively privileged classes. Dora Sampaio addresses the 'returnretirement' nexus within IRM, responding to the question raised by Bolzman et al. (2006): 'What to do after retirement?' Bolzman et al. posed this question to Spanish and Italian labour migrants reaching retirement in Switzerland. Sampaio also opens up a new geographical frontier by locating her study in the Azores, a Portuguese mid-Atlantic archipelago with a long history of emigration and return. Based on interviews with 31 returned and retired Azorean labour migrants from the USA and Canada, and 14 interviews with older Azorean non-migrants, Sampaio opens up new analytical frontiers in IRM studies. She asks two broad questions. First, what experiences, imaginaries and discourses of ageing are brought back by the returnees from North America? Second, how are these discourses and practices of ageing reacted to by the locals in the Azores? Within the intersecting fields of transnational migration and cultures of ageing, Sampaio focuses on three themes dominant in the narratives she collected: (a) health and the ageing body, (b) care in older age, and (c) attitudes towards work and physical activity in later life.

The overall result, in synthesis, is that 'hybrid cultures of ageing' are produced by the experience of decades of life and work in North America followed by return to the Azores. Regarding the first theme, returnees presented themselves as the embodiment of healthy ageing through their exposure to hard work and models of active ageing in North America. Through careful saving, most had been able to retire and return in their fifties; they contrasted their own vitality with that of the older locals whom they portrayed as lazy and overweight. ${ }^{3}$ The second theme, ageing care, reveals a convergence with non-migrant norms of older-age care, namely that this is best carried out with family support. The islands' small villages and intimate neighbourhoods are a more congenial spatial setting for enjoying and surviving life in older-age, unlike the spread-out suburbs of North America with their high dependency on car-driving. The Azores also offers more affordable ageing health-care options compared to the USA. Nevertheless, some returnees do articulate a more independent view of care in old-age, derived from their exposure to the neoliberal, self-reliant model of North America. Regarding the third theme, the returnees generally kept physically active through involving themselves in 'hobby work' - unlike the locals who (in the view of the returnees) had lost the work ethic and the habit of 'keeping busy' in later life. A similar contrast was drawn in terms of mental outlook: the returnees saw themselves as open-minded and still ambitious, whereas the locals were seen as introverted and apathetic, interested only in local issues and gossiping.

For their part, the non-migrants react in ambiguous ways to the returnees' views and embodiment of ageing. Whilst some acknowledge that they have brought back new ideas regarding active ageing, diet and lifestyle, others deride them as novos 
ricos, lacking cultural capital and social connections. In their eyes, those who return do so purely because of nostalgia and admiration for the Azorean lifestyle.

In the final paper of the special issue, Aija Lulle 'reverses' the ageing-migration nexus and creates a new frontier for 'retirement'. Taking the case of Latvian older women who approach pension age in the harsh neoliberal economic climate of post-socialism, with severely weakened welfare systems, she documents how many embark on a new working career in the UK and Nordic countries. They migrate in late middle-age or later in order to escape old-age poverty, to secure a better survival for themselves and their family members, and also out of a sense of adventure and self-realisation. The collapse of the Soviet Union (of which Latvia was a part) in 1991 and joining the European Union in 2004 were the two key temporal frontiers which guided Latvia along the path to Europe and enabled the emigration of a significant proportion of the country's population, including older migrants. Impoverishment of older women, many of them widowed, divorced or separated, was particularly acute in the wake of the 2008 financial crisis, which hit Latvia hard.

For these older migrants, active ageing, instead of applying to leisure and lifestyle pursuits, is achieved through employment abroad. They take jobs in seasonal agriculture, factory work, domestic cleaning and the care sector. These may be humble forms of work, but pride is taken in doing the jobs well and attaining not only an income and financial independence, but also a sense of self-worth. They have modest aspirations for a 'good life' - very different from what a 'good life' comprises for middle-class lifestyle migrants à la Benson (2011). Many are motivated simply by working abroad for sufficient years to secure a basic pension from the UK, Norway or Finland, which will support them in their non-working old age back in Latvia. Lulle's paper thus launches a debate on new retirement migration frontiers in a context of global inequalities structured not between the global North and South, but the 'global East' set alongside migration destinations in Western Europe where new forms of work-in-retirement can ensure the survival of a population of older women marginalised by the neoliberal forces of the post-socialist transition.

\section{Notes}

1 Papers in this special issue were first presented at the session entitled 'New Frontiers in International Retirement Migration' at the Annual IMISCOE Conference, Rotterdam, 28-30 June 2017, and a similar session on 'Materialities and Ageing Migrants' at the following year's IMISCOE conference in Barcelona, 2-4 July 2018.

2 Actually, the transnational element was not so evident in her account. Indeed, rather than a transnational community, O'Reilly's (2000) ethnography portrays the British in Fuengirola as a community detached both from its origins and from the local Spanish population. Most British residents speak very little Spanish and are not integrated into local society, except that fraction made up of other British 'expats'. Moreover, many construct a narrative of 'bad Britain', justifying their decision to settle in Spain by reference to the cold, wet climate of their origin country, its high cost of living, problems of crime and urban degradation, and poor treatment of older people.

3 We draw attention to two surprises emerging from this finding. First, the return of these healthy, active early retirees seems to contradict the established view in the literature that it is the less-healthy migrants who are more likely to return. Sampaio acknowledges this, but does not mention a second curiosity: that there is no reference to the obesity crisis in North America, particularly the USA. 


\section{References}

Adey P (2010) Mobilities. London: Routledge.

Åkerland U and Sandberg L (2015) Stories of lifestyle mobility: representing self and place in the search for the 'good life'. Social \& Cultural Geography 16, 351-370.

Balkir C and Kirkulak B (2009) Turkey, the new destination for international retirement migration. In Fassmann H, Haller M and Lane D (eds), Migration and Mobility in Europe: Trends, Patterns and Control. Cheltenham, UK: Edward Elgar, pp. 123-143.

Banks SP (2004) Identity narratives of American and Canadian retirees in Mexico. Journal of Cross-cultural Gerontology 19, 361-381.

Barrett A and Mosca I (2013) Social isolation, loneliness and return migration: evidence from older Irish adults. Journal of Ethnic and Migration Studies 39, 1659-1677.

Baykara-Krumme H (2013) Returning, staying, or both? Mobility patterns among elderly Turkish migrants after retirement. Transnational Social Review 3, 11-29.

Bender D, Hollstein T and Schweppe C (2018) International retirement migration revisited: from amenity seeking to precarity migration? Transnational Social Review 8, 98-102.

Benson M (2011) The British in Rural France: Lifestyle Migration and the Ongoing Quest for a Better Way of Life. Manchester, UK: Manchester University Press.

Benson M (2013) Postcoloniality and privilege in new lifestyle flows: the case of North Americans in Panama. Mobilities 8, 313-330.

Benson M (2015) Class, race, privilege: structuring the lifestyle migrant experience in Boquete, Panama. Journal of Latin American Geography 14, 19-37.

Benson M and O'Reilly K (2009a) Lifestyle Migration: Expectations, Aspirations and Experiences. Farnham, UK: Ashgate.

Benson M and O'Reilly K (eds) (2009b) Migration and the search for a better way of life: a critical exploration of lifestyle migration. Sociological Review 57, 608-625.

Benson M and Osbaldiston N (2014) Toward a critical sociology of lifestyle migration: reconceptualising migration and the search for a better way of life. Sociological Review 64, 407-423.

Benson M and Osbaldiston N (eds) (2016) Understanding Lifestyle Migration: Theoretical Approaches to Migration and the Quest for a Better Way of Life. Basingstoke, UK: Palgrave Macmillan.

Bolognani M (2014) The emergence of lifestyle reasoning in return considerations among British Pakistanis. International Migration 52, 31-42.

Bolzman C, Fibbi R and Vial M (2006) What to do after retirement? Elderly migrants and the question of return. Journal of Ethnic and Migration Studies 32, 1359-1375.

Bolzman C, Fokkema T, Guissé I and van Dalen D (2021) Starting a new life in the south? Swiss, Dutch and Flemish ageing in Morocco: a lifecourse perspective. Ageing \& Society, this issue.

Botterill K (2016) Diminished transnationalism? Growing older and practising home in Thailand. In Walsh K and Näre L (eds), Transnational Migration and Home in Older Age. London: Routledge, pp. 99-111.

Botterill K (2017) Discordant lifestyle mobilities in East Asia: privilege and precarity of British retirement migrants in Thailand. Population, Space and Place 23, e2011.

Casado-Díaz MA, Kaiser C and Warnes AM (2004) Northern European retired residents in nine southern European areas: characteristics, motivations and adjustment. Ageing \& Society 24, 353-381.

Castles S (2010) Understanding global migration: a social transformation perspective. Journal of Ethnic and Migration Studies 36, 1565-1586.

Cela E and Bettin G (2018) Returning to the country of origin in later life: longitudinal evidence from the German Socio-Economic Panel. Area 50, 483-491.

Cerase FP (1974) Expectations and reality: a case study of return migration from the United States to Italy. International Migration Review 8, 245-262.

Ciobanu RO and Ramos AC (2016) Is there a way back? A state-of-the-art review of the literature on retirement return migration. In Karl U and Torres S (eds), Ageing in Contexts of Migration. London: Routledge, pp. 96-107.

Cresswell T (2006) On the Move: Mobility in the Modern Western World. London: Routledge.

De Coulon A and Wolff F-C (2010) Location intentions of immigrants at retirement: stay/return or go 'back and forth'? Applied Economics 42, 3319-3333. 
de Haas H and Fokkema T (2010) Intra-household conflicts in migration decision-making: return and pendulum migration in Morocco. Population and Development Review 36, 541-561.

Dixon D, Murray J and Gelatt J (2006) America's Emigrants: US Retirement Migration to Mexico and Panama. Washington, DC: Migration Policy Institute.

Escher A and Petermann S (2014) Marrakesh Medina: neo-colonial paradise for lifestyle migrants? In Janoschka M and Haas H (eds), Contested Spatialities: Lifestyle Migration and Residential Tourism. London: Routledge, pp. 29-46.

Fokkema T, Cela E and Witter Y (2016) Pendular migration of older adults: misconceptions and nuances. In Horn V and Schweppe C (eds), Transnational Ageing: Current Insights and Future Challenges. London: Routledge, pp. 141-161.

Friedrich K, Kellaher L and Torres S (eds) (2004) Special issue: Older migrants in Europe. Ageing \& Society 24, 307-475.

Gambold L (2013) Retirement abroad as women's aging strategy. Anthropology and Aging Quarterly 34, 1953-1971.

Ganga D (2006) From potential returnees into settlers: Nottingham's older Italians. Journal of Ethnic and Migration Studies 32, 1395-1413.

Gehring AJ (2019) Pensioners on the Move: A Socio-legal Study on Retirement Migration from the Netherlands to Spain and Turkey ( $\mathrm{PhD}$ thesis). Radboud University, Nijmegen, The Netherlands.

Green P (2014) Contested realities and economic circumstances: British later-life migrants in Malaysia. In Janoschka M and Haas H (eds), Contested Spatialities: Lifestyle Migration and Residential Tourism. London: Routledge, pp. 145-157.

Gustafson P (2001) Retirement migration and transnational lifestyles. Ageing \& Society 21, 371-394.

Gustafson P (2009) Your home in Spain: residential strategies in international retirement migration. In Benson M and O'Reilly K (eds), Lifestyle Migration: Expectations, Aspirations and Experiences. Farnham, UK: Ashgate, pp. 69-86.

Hayes M (2014) 'We gained a lot over what we would have had': the geographic arbitrage of North American lifestyle migrants to Cuenca, Ecuador. Journal of Ethnic and Migration Studies 40, 1953-1971.

Hayes M (2018) Gringolandia: Lifestyle Migration Under Late Capitalism. Minneapolis MN: University of Minnesota Press.

Hayes M (2021) 'Sometimes you gotta get out of your comfort zone': retirement migration and active ageing in Cuenca, Ecuador. Ageing \& Society, this issue.

Hayes M and Pérez-Gañán R (2017) North-South migrations and the asymmetric expulsions of late capitalism: global inequality, arbitrage, and new dynamics of North-South transnationalism. Migration Studies 5, 116-135.

Hoggart K and Buller H (1995) Retired British home owners in rural France. Ageing \& Society 15, 325-353.

Horn V, Schweppe C, Bender D and Hollstein T (2016) Moving (for) elder care abroad: the fragile promises of old-age care-facilities for elderly Germans in Thailand. In Horn V and Schweppe C (eds), Transnational Ageing: Current Insights and Future Challenges. London: Routledge, pp. 163-177.

Howard RW (2008) Western retirees in Thailand: motives, experiences, wellbeing, assimilation and future needs. Ageing \& Society 28, 145-163.

Huber A (2003) Sog de Südens: Altersmigration von der Schweiz nach Spanien am Beispiel Costa Blanca. Zurich: Seismo.

Janoschka M and Haas H (eds) (2014) Contested Spatialities: Lifestyle Migration and Residential Tourism. London: Routledge.

King R (2012) Sunset migration. In Martiniello M and Rath J (eds), An Introduction to International Migration Studies. Amsterdam: Amsterdam University Press, pp. 281-304.

King R, Warnes T and Williams A (eds) (1998) Special issue: International retirement migration in Europe. International Journal of Population Geography 4, 87-200.

King R, Warnes T and Williams A (2000) Sunset Lives: British Retirement Migration to the Mediterranean. Oxford: Berg.

King R, Lulle A, Conti F and Mueller D (2016) Eurocity London: a qualitative comparison of graduate migration from Germany, Italy and Latvia. Comparative Migration Studies 4, 1-22.

King R, Cela E, Morettini G and Fokkema T (2019) The Marche: Italy's new frontier for international retirement migration. Population, Space and Place 25, e2241. 
King R, Cela E, Fokkema T and Morettini G (2021) International retirement and later-life migrants in the Marche region, Italy: materialities of landscape, 'home', lifestyle and consumption. Ageing \& Society, this issue.

Lardiés Bosque R, Guillén JC and Montes-De-Oca V (2016) Retirement migration and transnationalism in northern Mexico. Journal of Ethnic and Migration Studies 42, 816-833.

Lulle A (2021) Reversing retirement frontiers in the spaces of post-socialism: active ageing through migration for work. Ageing \& Society, this issue.

Lulle A and King R (2016) Ageing well: the time-spaces of possibility for older female Latvian migrants in the UK. Social \& Cultural Geography 17, 444-462.

Miles A (2015) Healthcare imaginaries and retirement migration to Cuenca, Ecuador. Journal of Latin American Geography 14, 39-55.

Myklebost H (1989) Migration of elderly Norwegians. Norsk Geografisk Tidsskrift 43, 191-213.

Oliver C (2008) Retirement Migration: Paradoxes of Ageing. London: Routledge.

Oliver C (2016) Ageing, embodiment and emotions in orientations to home: British retirement migration to Spain. In Walsh K and Näre L (eds), Transnational Migration and Home in Older Age. London: Routledge, pp. 188-198.

Ono M (2015) Commoditization of lifestyle migration: Japanese retirees in Malaysia. Mobilities 10, 609-627.

O'Reilly K (2000) The British on the Costa del Sol: Transnational Identities and Local Communities. London: Routledge.

O'Reilly K (2003) When is a tourist? The articulation of tourism and migration in Spain's Costa del Sol. Tourist Studies 3, 301-317.

Rodríguez V and Egea C (2006) Return and the social environment of Andalusian emigrants in Europe. Journal of Ethnic and Migration Studies 32, 1377-1393.

Rodríguez V, Casado Díaz MA and Huber A (eds) (2005) La Migracion de Europeos Retirados en España. Madrid: Consejo Superior de Investigaciones Científicas.

Rojas V, LeBlanc HP and Sunil TS (2014) US retirement migration to Mexico: understanding issues of adaptation, networking and social integration. Journal of International Migration and Integration 15, 257-273.

Sampaio D (2018) A place to grow older ... alone? Living and ageing as a single older lifestyle migrant in the Azores. Area 50, 459-466.

Sampaio D (2021) Languages of othering and cultural hybridity. Transnational cultures of ageing in the context of return to the Azores. Ageing \& Society, this issue.

Sampaio D and King R (2019) 'It's not everybody that wants to stay on a remote island': understanding distinction in the context of lifestyle migrants growing older in the Azores. Journal of Rural Studies 72, 186-195.

Sardinha J (2015) Idyllic seekers and liminal beings: lifestyle migrants in central Portugal. In Torkington K, David I and Sardinha J (eds), Practising the Good Life: Lifestyle Migration in Practices. Newcastle upon Tyne, UK: Cambridge Scholars, pp. 33-51.

Scuzzarello S (2020) Practising privilege: how settling in Thailand enables older Western migrants to enact privilege over local people. Journal of Ethnic and Migration Studies 46, 1606-1628.

Sunil TS, Rojas V and Bradley DE (2007) United States' international retirement migration: the reasons for retiring to the environs of Lake Chapala, Mexico. Ageing \& Society 27, 489-520.

Toyota M (2016) Confronting economic precariousness through international retirement migration: Japan's old-age 'economic refugees' and Germany's 'exported grannies'. In Rickly-Boyd JM, Hannam K and Mostafanezhad M (eds), Tourism and Leisure Mobilities: Politics, Work and Play. London: Routledge, pp. 134-146.

Toyota M and Biao X (2012) The emerging transnational 'retirement industry' in Southeast Asia. International Journal of Sociology and Social Policy 32, 708-719.

Truly D (2002) International retirement migration and tourism along the Lake Chapala Riviera: developing a matrix of retirement migration behaviour. Tourism Geographies 4, 261-281.

Urry J (2007) Mobilities. Cambridge: Polity.

Warnes AM and Patterson G (1998) British retirees in Malta: components of the cross-national relationship. International Journal of Population Geography 4, 113-133. 
Warnes AM, Williams A, Kellaher L and Rodríguez V (eds) (2006) Special issue: Older migrants in Europe: experiences, exclusion and constructive accommodation. Journal of Ethnic and Migration Studies 32, 1257-1427.

Williams AM, King R and Warnes AM (1997) A place in the sun: international retirement migration from Northern to Southern Europe. European Urban and Regional Studies 4, 115-134.

Williams AM, King R, Warnes AM and Patterson G (2000) Tourism and international retirement migration: new forms of an old relationship in southern Europe. Tourism Geographies 2, 28-49.

Wong KM and Musa G (2015) International second home retirement motives in Malaysia: comparing British and Japanese retirees. Asia Pacific Journal of Tourism Research 20, 1041-1062.

Cite this article: King R, Cela E, Fokkema T (2021). New frontiers in international retirement migration. Ageing \& Society 41, 1205-1220. https://doi.org/10.1017/S0144686X21000179 